\title{
Government Subsidies and Revenue Sharing Decisions for Port and Shipping Service Supply Chain in Emission Control Areas
}

\author{
Bing Han $\mathbb{D}^{1,2}$ Xia Pan, ${ }^{1,2}$ and Yu Zhou $\mathbb{D i D}^{1,2}$ \\ ${ }^{1}$ Shipping Economics and Management College, Dalian Maritime University, Dalian 116026, China \\ ${ }^{2}$ Collaborative Innovation Center for Transport Studies, Dalian Maritime University, Dalian 116026, China \\ Correspondence should be addressed to Bing Han; hanbing0610@163.com and Yu Zhou; woshizhouyu303@163.com
}

Received 10 June 2020; Revised 15 September 2020; Accepted 5 October 2020; Published 29 October 2020

Academic Editor: Dongjoo Park

Copyright (c) 2020 Bing Han et al. This is an open access article distributed under the Creative Commons Attribution License, which permits unrestricted use, distribution, and reproduction in any medium, provided the original work is properly cited.

As the core of the port and shipping service supply chain system, the port and shipping companies must urgently solve the problem of how to balance emissions, costs, and benefits with the gradual extension of China's emission control area (ECA) and the stringent emission requirements. From the perspective of system optimization, this research constructs a revenue sharing model of the port and shipping service supply chain and deals with the revenue sharing decision-making problem of the secondary service supply chain after port enterprises and shipping enterprises joining the government subsidy mechanism driven by ECA's policy. Research shows that the government subsidy mechanism directly affects the profit of the port and shipping service supply chain, which is the key factor in implementing the ECA's policy and promoting the emission reduction of the port and shipping enterprises. The revenue sharing of the port and shipping enterprises plays a decisive role in the revenue of the shipping enterprises. Cooperative emission reduction mechanism should be led by port enterprises to promote the balance between revenue and emission reduction in the supply chain system. Results provide a reference for the Chinese government to formulate corresponding incentives and subsidy policy under the new ECA's regulations as well as solving the problems of how to balance emissions reduction and cost improvement for port and shipping enterprises.

\section{Introduction}

Faced with increasingly strict port environmental pollution and emission control requirements, port and shipping enterprises must take a series of reform measures to promote the green and sustainable development of port and shipping service supply chain. Port and shipping emissions are the third-largest source of pollution in the world. Nearly $70 \%$ of marine emissions are discharged within $400 \mathrm{~km}$ of land [1], which generates huge greenhouse gases $[2,3]$ and also brings serious sulfur pollution problems to coastal areas and port cities with a large throughput. With the increasing environmental concerns brought about by the increase in global seaborne trade, the emission control areas (ECAs) proposed by the International Maritime Organization (IMO) came into effect in the Baltic Sea for the first time in 2006, including the Baltic Sea, the North Sea, North America, the United States, and the Caribbean four major emission control areas [4]. In 2015, China established three major emission control zones, including the Pearl River Delta, the Yangtze River Delta, and the Bohai Sea Watershed. It was then comprehensively upgraded in 2019 to further limit the range of sulfur content of fuel used in the emission control zones. Mandatory requirements are imposed on the use of shore power systems. The increasingly strict ECA poses a huge challenge to the service supply chain system of port and shipping companies as reflected in the significant increase in operating costs of port and shipping companies, especially shipping companies. The Wood Mackenzie consulting firm predicts that the sulfur limit for marine oils from $3.5 \%$ to $0.5 \%$ by 2020 will cause shipping companies to spend an additional $\$ 60$ billion a year. For shipping companies, a large number of ships need updating into "environmental protection vessels" [5] and thus ensure that ships will reduce greenhouse gas emissions by $20 \%$ before 2020 . "Ecoship" uses clean fuel oil. A few years must pass before adequate 
LNG infrastructure is implemented, although LNG is quite promising at present [6]. In addition, with the gradual enhancement of ship emission requirements in the emission control area, some ship operators choose to sail a longer distance than the others to avoid sailing within ECA [7], which results in the transfer of emission pollution to adjacent areas and the total emission not being reduced. Therefore, the substantial reduction of ship emissions still depends on the technological advancement of shipping companies [8], but a huge cost is required for ports and shipping companies. At present, a large number of studies have focused on the transformation of shipping companies, but the supervision of the entire department and social pressure largely drive most of their participation in emission reduction programs [9]. As the restriction of emission control area increases, some shipping companies may even stop some routes or turn to land transportation because they are faced with huge cost pressures [10].

Therefore, with the implementation of an emission limit plan in an emission control area, it is urgent to solve the problem of how to balance cost increase and its benefits from emission reduction. The introduction of new ECA regulations (e.g., sulfur-restricted orders) will significantly increase the shipping companies' demand for emission reduction technologies, but the questions of who will bear the costs and how to bear the resulting costs have not been effectively resolved. Radwan et al. [11] analyzed the container terminal data of Djibouti and showed that power demand, investment cost, and power cost were the main factors that hindered the installation of the shore power system, which was the most fundamental obstacle to the economic cost. At present, Schinas and Metzger [12] envisage the problem of increasing costs caused by ECA rules by proposing a concept of shared savings, wherein risks and benefits are shared by ship operators and green technology providers. Technical costs are involved in realizing green shipping, such as ship improvement costs and shore power system equipment costs. Thus, the enthusiasm of relevant enterprises for green transformation will be substantially reduced if the port and shipping companies bear the burden themselves. This scenario will lead to a bypassing of the ECA region, consequently causing other social problems. Sharing revenue or sharing costs is an effective mitigation method for shipowners who currently lack the funds to purchase green emission reduction technology.

In summary, according to the management idea of supply chain, this study examines the cost sharing and revenue sharing of the two-stage supply chain composed of port enterprises and shipping companies under ECA restrictions. It then introduces a government subsidy mechanism to solve the dilemma between the cost increase caused by emission reduction and expected benefits. The government subsidy and revenue sharing mechanism are attractive to ports and shipping companies. Under the corresponding subsidy policy, shipping and port companies can effectively respond to the implementation of ECA policies through revenue sharing while simultaneously promoting the implementation of ECA policies and obtaining a positive effect on emission reduction. Based on this, the authors mainly address the following questions in this paper: 1. How should the government subsidize the port and shipping enterprises after they update the related system? and whether the profits of the port and shipping enterprises are improved after subsiding. 2. Whether the two benefits can be coordinated through a revenue sharing contact after government subsidies. In this paper, our main theoretical contributions are proposing a concept of a green index of emission control area to measure the technological upgrading effect of port and shipping enterprises and providing a revenue sharing contract for balancing the benefit and cost caused by the upgrading equipment; in practice, this paper provides suggestions for the Chinese government to formulate corresponding incentives and subsidy policy under the new ECA's regulations.

\section{Literature Review}

2.1. Implementation of Relevant Policies. The current theories focus on the policy research of emission control area (ECA) and the influence mechanism research on ports and shipping enterprises.

In terms of relevant policies and implementation, the MARPOL Convention proposes four major emission control zones, including the Baltic Sea and the English Channel. Controlling the sulfur content in the controlled area is required within $0.1 \%$ [1]. In 2010, many ports, such as the Rotterdam and Amsterdam Ports, developed and implemented the Ship Environment Index (ESI) plan, which is aimed at port and cargo carriers and provides corresponding port preferential tax for ships on the basis of the calculated ESI total score [13]. Gothenburg and some Swedish companies started implementing the Clean Shipping Index (CSI) in 2007. In addition, the Long Beach Port of the United States promoted the large-scale construction of green ports in 2005 and proposed the "Green Port Policy (GPP)." Singapore, South Korea, and Japan have also slowly established a carbon emission reporting mechanism for ships. The Singapore Maritime Green Initiative launched by the Singapore government proposes three major green planning and invests approximately 70 million dollars in five years to encourage the development of green technologies and the use of clean energy and to reduce emissions of carbon oxide and sulfur oxide. The "Green Port Rating Standard" issued by China in 2013 specified the evaluation method of green port level, divided the green port into three levels, and required mandatory classification for energy conservation and emission reduction actions. In 2015, the Ministry of Transportation issued the first implementation plan for the ship emission control in the Pearl River Delta, the Yangtze River Delta, and the Bohai Rim Region. In July 2018, the coastal ship emission control zone was extended to 12 nautical miles across the country. At the same time, further requirements were made on the electricity and fuel consumption of ships. From the domestic and international perspectives, the ECA policy sees a tightening trend.

2.2. Measures for Ports and Shipping Enterprises. The research on the impact of ECA-related policy implementation on the port and shipping system includes stakeholder 
response, government subsidy mechanism, route network optimization, and ship combination. Lee and Nam [5] studied the understanding, rules, and market conditions of green emission reduction by shipyards, shipping companies, and governments in some major EU countries and introduced suggestions on establishing a partnership between shipyards and shipping companies to increase technology investment and research and development of ecologically friendly ships. The study has shown that shipping enterprises with the capacity to undergo continuous improvements are conducive to the development of enterprise performance [14]. Yuen et al. [15] analyzed sustainable shipping by studying stakeholder and behavioral theories and concluded that the pressure and behavior of shipping company stakeholders directly affect their attitude and behavior toward sustainable shipping. Many scholars have conducted much research on the improvement of green and environmentally friendly ships. The design of green ships is the most important factor for the company to achieve sustainable shipping [16]. The design can promote the development of ship green technology by stimulating different environmentally friendly ships [17]. Abadie and Goicoechea [18] studied the impact of ship investment and fuel costs on the four scenes: installation of dual or diesel engines and a scrubber or not, believing that a dual engine without scrubber is an optimal choice in the short term. According to Abadie et al. [19], extending the remaining life of the ship also lengthens the travel time to travel in the ECA area and the sea and improves the installation of the scrubber. For existing container terminals, changing fuel facilities and using sustainable biodiesel fuel will significantly reduce carbon dioxide emissions [20]. Krozer et al. [21] studied the relevant improvement measures of ships on the basis of the improvement scheme of short-term shipping based on environmental friendliness and cost-effectiveness; indeed, the latter reduced the life cycle cost of ships but required additional initial investment. A large amount of literature is devoted to ECA speed optimization and ship emission. Woo and Moon [22] studied the relationship between speed, $\mathrm{CO}_{2}$ emissions, and operating costs; then, they found the optimal speed to minimize $\mathrm{CO}_{2}$ emissions with minimum operating costs and meet the IMO's emission reduction target. Zhen et al. [23] replanned the cruise plan by optimizing the speed, navigation mode, and port of call sequence to achieve the goal of reducing emissions with minimal cost. Similarly, Sheng et al. [24] aimed to minimize the cost and establish an optimization model on the basis of the speed and fleet size to reduce ship emissions in the emission control area. Corbett et al. [25] studied the effects of carbon dioxide emissions from ships under fuel tax and speed limit, respectively.

Some scholars have indicated that the future development direction of green shipping is to establish a green shipping system and shipping policy from the perspective of the supply chain [26]. Acciaro et al. [27] developed a method to quantify the degree of innovation success in the sustainable development of the harbor environment. Moreover, an index level (IR) for the current unspecified Energy
Efficiency Design Index Objective (EEDI) is proposed, which is a cost-benefit assessment of the current mitigation measures [28]. In terms of revenue, Qiu et al. [29] established two container allocation models on the basis of ship sharing. The ship sharing can generate liner company income through numerical analysis along with the Sino-Indian Economic Corridor.

2.3. Supply Chain Coordination. Many researchers and practitioners have focused on supply chain coordination during the last decade. Modak and Kelle [30] regarded social work donation (SWD) and investment recovery as two tools of corporate social responsibility (CSR). They proposed profit maximization under a carbon emissions tax and showed the synergy between SWD, product recycling, and carbon emission. Schinas and Metzger [12] also proposed the concept of revenue sharing to promote the participation of shipping companies in active emissions reduction. Modak and Kelle [31] discussed a coordination problem of a dualchannel supply chain under centralized and decentralized systems and use the generalized asymmetric Nash bargaining for surplus profit distribution to eliminate channel conflict. Panda et al. [32] believed that there should be a limit of recycling for optimal benefit after studying the channel coordination problem of corporate social responsibility (CSR) for the closed-loop supply chain. Considering the cost of greenhouse gas emissions, Modak et al. [33] adopted a revenue sharing contract and asymmetric Nash bargaining strategy to solve the channel conflict and share surplus profit. Hsueh [34] developed a revenue sharing contract embedding corporate social responsibility (RS-CSR) to coordinate a two-tier supply chain. Modak [35] studied the effects of price and online delivery lead time on the revenue of supply chain members, and the optimal strategy of retailers in dual channel. Although much research on supply chain coordination can be found, there are only a few studies related to ports and shipping companies.

In summary, the current theoretical results provide an important basis for the design of a government subsidy mechanism and revenue sharing mechanism to promote emission reduction of port and navigation systems under the ECA. The following aspects can further be developed by combining with the integrated thinking of the service supply chain. First, the implementation of ECA drives ports and ships to implement emission reduction policies. Therefore, exploring the balance between interests and costs between ports and shipping companies is necessary. Second, government-led exploration is necessary after upgrading the emission reduction equipment for ports and shipping companies. The subsidy of ports and shipping companies and the benefits of port and shipping companies will be improved after subsidies. Driven by increasingly strict ECA emission policies, realizing green emission reduction requires the joint action of multiple entities of government, port, and shipping enterprises. Therefore, achieving the aim of multiparty linkage and collaborative optimization through a rational design of subsidy and sharing mechanisms is necessary. 


\section{Model Development}

This section aims to construct models related to port and shipping company's profits and their emissions from operations inside an ECA. Before models are established, the following hypotheses are introduced:

(1) The market demand between $[A, B]$ obeys the random distribution of mean $\mu$ and standard deviation $\sigma$; then, its probability density function is $f(x)$, and its distribution function is $F(x)$.

(2) With the country's emphasis on pollution control in emission areas, the ships' emissions have been strictly defined further since January 1, 2019. Ships that have not been upgraded or have no clean energy replacement are barred from entering the emission control zone. The updated environmentally friendly ship has a new competitive advantage because of the legal and policy support. Therefore, the market demand for updated ships has increased. The demand is subject to $(\mu+e \mu)$ to ensure that the increase is within a reasonable range [36], and standard deviation is $\sigma$. The probability density function is $f(x-e \mu)$, and the distribution function is $F(x-e \mu)$.

(3) The unit service cost of shipping enterprises will change after the replacement of clean fuel. The variable unit cost is transferred to the infrastructure investment cost to facilitate calculation. Therefore, the unit service cost of shipping enterprises to customers will not change. Similarly, considering that the unit service cost provided by the port to shipping enterprises may also change after the port is updated, the changed part is also transferred to the port infrastructure investment and construction cost. Thus, the emission reduction will remain unchanged before and after the upgrade.

3.1. Parameter Hypothesis. As shown in Figure 1, in the first phase, shipping companies transport goods out of ports. Ships staying at the port will incur a series of costs such as loading and unloading, handling costs, and cargo storage costs. In the second stage, shipping companies deliver the goods to the customer and charge the customer the corresponding shipping costs.

$c_{p}$ : the unit operating cost incurred by the port for providing services to shipping companies is the unit cost of loading, unloading, and handling provided by the port to the ship.

$c_{c}$ : the unit service cost of the shipping enterprise to the customer is the unit transportation cost of the ship, which typically includes daily expenses, fuel costs, and port charges.

$w$ : the unit service fees charged by the port to shipping companies generally include loading and unloading fees, cargo storage fees, and parking fees.

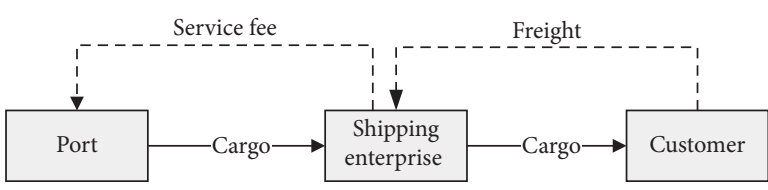

Figure 1: Port and shipping service supply chain.

$q$ : the number of port ordering services provided by shipping enterprises.

$p$ : the unit service price charged by the shipping enterprise to customers, that is, the unit freight rate charged.

$t$ : the subsidy coefficient of the government to the port's unit service quantity depends on the port service quantity (reflecting the port service scale) and the green index of the emission control area.

$\lambda$ : the subsidy coefficient of the government to shipping enterprises is only related to the green index of the emission control zone.

$k_{p}$ : port investment cost coefficient, a small coefficient means low cost of port investment construction.

$k_{c}$ : shipping company investment cost coefficient; similarly, a small coefficient means low cost of shipping companies' investment construction.

$e$ : green index in the emission control area $e \in[0,1]$, which is used to measure the technological upgrading effect of port and shipping enterprises.

\subsection{Formulations of Port and Shipping Company's Revenue}

3.2.1. Basic Model. In the two-stage port and shipping service supply chain, the profit of one shipping enterprise can be expressed as follows:

$$
\pi_{c}=p(x \wedge q)-w q-c_{c} q
$$

where $p(x \wedge q)$ is the revenue of the shipping enterprise, $x \wedge q$ is the smallest of $x$ and $q, w q$ is the total service fee charged by the port to the shipping enterprise, and $c_{c} q$ is the service cost of the shipping enterprise.

Profit of the port:

$$
\pi_{p}=w q-c_{p} q
$$

where $w q$ is the service fee charged by the port to the shipping enterprise, which is the revenue of the port. $c_{p} q$ is the cost of service provided by the port.

As market demand $x$ is subject to a random distribution with a mean value of $\mu$ and a standard deviation of $\sigma$ in the $[A, B]$ range, the expected profit of shipping enterprises can be transformed into

$$
\left.E\left(\pi_{c}\right)=p\left(\int_{A}^{q} f(x) x \mathrm{~d} x+\int_{q}^{B} q f(x) \mathrm{d} x\right)\right)-w q-c_{c} q .
$$


The second derivative of formula (3) can be obtained as follows:

$$
\frac{\partial^{2} E\left(\pi_{c}\right)}{\partial q^{2}}=-p f(q)<0 .
$$

The above formula indicates that $E\left(\pi_{c}\right)$ is a concave function of the order quantity and therefore has a maximum value. The optimal order quantity of a shipping enterprise can be obtained by the first derivative, as shown in the following equation:

$$
q^{o}=F^{-1}\left(1-\frac{w+c_{c}}{p}\right) .
$$

Therefore, before technology is updated, the optimal profits of shipping enterprises and ports are

$$
\begin{aligned}
& \pi_{c}^{o}=p\left[\int_{A}^{q^{o}} f(x) x \mathrm{~d} x+\int_{q^{o}}^{B} q f(x) \mathrm{d} x\right]-w q^{o}-c_{c} q^{o}, \\
& \pi_{p}^{o}=w q^{o}-c_{p} q^{o} .
\end{aligned}
$$

3.2.2. After Equipment Updating. Port equipment updates include the provision of shore power systems, transformation of field bridges, trailers, and other large energy emission sources [37]. Several methods to reduce the nitrogen and sulfur content of ship emissions for shipping companies are available. One is using fuel conversion and the other is installing a washing system at the stern of the ship to purify emission or using liquefied natural gas (LNG) [37-39].

After the port and shipping companies invest in emission reduction equipment and technology, the government will subsidize both companies according to the green index in the emission control areas.

The calculation formula of the green index of the emission control area is $e=r \times(\mathrm{ESI} / 100)$.

The Ship Environment Index (ESI) is one of the leading green incentive shipping programs in the industry. If the ship meets the corresponding conditions, a fee discount tax can be obtained to promote the upgrading of ship facilities. The index has specific measures for ships, which ranges in size from 0 to 100. $r$ is the impact factor of the port. The emission control areas' green index is affected by the ship's own emissions and also by the port daily operations.

The green index of unit service in the emission area was 0 because the port and aviation enterprises did not participate in the calculation of the green index before updating the equipment.

A law of diminishing marginal effect exists between the construction investment of port and shipping enterprises and the green degree of ECAs. Assuming that the cost of investment of both enterprises is directly proportional to the square of the green index $e$ in the emission control zone; then, the cost of investment and construction of port can be expressed by $(1 / 2) k_{p} e^{2}$, of which $k_{p}$ is the investment cost coefficient of the port. The investment of shipping enterprises is $(1 / 2) k_{c} e^{2}$, and $k_{c}$ is the investment cost coefficient of shipping enterprises.

Government subsidies for ports depend on two aspects, namely, green index and order quantity, in the port and navigation service supply chain dominated by ports. A high green index means high sufficiency in the investment funds that can be used to update the technical equipment. The order quantity reflects the service density of a port, and a large order quantity suggests a large port throughput and increased importance for the emission control. For shipping enterprises, the government subsidy depends on the green index. A high green index means a high ship environmental index and reduced pollution level. Therefore, under the subsidy of the government, the profits of the port and shipping enterprises dominated by the port are as follows:

$$
\pi_{p}=w q-c_{p} q-\frac{1}{2} k_{p} e^{2}+t q e .
$$

According to the first derivative property, when the maximum profit is obtained,

$$
\frac{\partial E\left(\pi_{p}\right)}{\partial e}=-k_{p} e+t q=0 .
$$

The optimal port green index is $e=\left(t q / k_{p}\right)$. Two meanings determine the optimal green index. First, the government can provide subsidies on the basis of the green index for ports and shipping enterprises. Second, the port can provide ships on the basis of the green index corresponding preferential policies. The green index of the emission control area is between 0 and 1 .

Formulae (8) shows that the optimal green index is positively correlated with the government subsidy coefficient and negatively correlated with the port investment cost coefficient. A high government subsidy coefficient means possibly obtaining a high green degree in the emission control area. A large investment cost coefficient means a low green index.

When the shipping enterprises are supported by government funds after updating the equipment, the profits are

$$
\pi_{c}=p(x \wedge q)-w q-c_{c} q-\frac{1}{2} k_{c} e^{2}+\lambda e,
$$

where $(0 \leq e \leq 1)$, and the desired profit is

$$
\begin{aligned}
E\left(\pi_{c}\right)= & p\left(\int_{A+e \mu}^{q} f(x-\mu e) x \mathrm{~d} x+\int_{q}^{B+e \mu} q f(x-\mu e) \mathrm{d} x\right) \\
& -w q-c_{c} q-\frac{1}{2} k_{c} e^{2}+\lambda e .
\end{aligned}
$$

When the green index is a constant, the optimal order quantity of shipping enterprises is as follows:

$$
q^{*}=F^{-1}\left(1-\frac{w+c_{c}}{p}\right)+\mu e .
$$

Combining formulas (8) and (11), the following result is obtained: 


$$
\begin{aligned}
& q^{*}=\frac{k_{p}}{k_{p}-t \mu} F^{-1}\left(1-\frac{w+c_{c}}{p}\right) \\
& e^{*}=q^{*} \frac{t}{k_{p}}=\frac{t}{\left(k_{p}-t \mu\right)} F^{-1}\left(1-\frac{w+c_{c}}{p}\right) .
\end{aligned}
$$

Conclusion 1. The optimal order quantity of a shipping enterprise is a decreasing function of the port investment cost coefficient. A high port investment cost coefficient means low investment efficiency and low green index.

Proposition 1. Impact on shipping companies: when $\lambda>\mu\left(c_{c}+w-p\right)+(1 / 2) k_{c} e$, the profit of shipping enterprise increases, and when $0<\lambda<\mu\left(c_{c}+w-p\right)+(1 / 2) k_{c} e$, the profit of shipping enterprise decreases. Proposition 1 illustrates the comparison of the profits of shipping companies before and after the implementation of the policy. The difference in profits reflects the strength of motivation of the shipping enterprise's renewal.

Proposition 2. When $\lambda>(1 / 2) k_{c} e-(C / e)$, shipping enterprises can gain profits. Here, the green index $e=\left(t /\left(k_{p}-\right.\right.$ $t \mu)) F^{-1}\left(1-\left(\left(w+c_{c}\right) / p\right)\right)$, the profit of shipping companies depends on the government's subsidy coefficient to shipping companies and on the government undefined subsidies to ports. Government subsidy to the port will increase the green index of the emission control area, and the increase in government subsidy to the shipping enterprise will increase the profit of the shipping enterprise. Proposition 2 shows the absolute situation of whether the shipping enterprises with the government subsidies are profitable after the implementation of the new policy and what the government needs to do is to avoid the shipping enterprises in a state of loss under the implementation of the new policy. $\lambda$ is the subsidy coefficient of the government to shipping enterprise which is only related to the green index of the emission control area. Once the green index of the emission control zone is determined, the government can take corresponding subsidies, which has practical significance.

Proposition 3. When the subsidy coefficient of the government for the unit service volume of the port meets $t>\left(\left(k_{p} q^{o}+2 \mu^{2}\left(w-c_{p}\right)\right) /\left(2 k_{p} \mu\left(w-c_{p}\right)\right)\right)$, the profit of the port is higher than before the upgrade. Port will have a higher possibility to update the harbor facilities because of the higher revenue. When $t$ is satisfied $0<t<\left(\left(k_{p} q^{o}+2 \mu^{2}\left(w-c_{p}\right)\right) /\right.$ $\left.\left(2 k_{p} \mu\left(w-c_{p}\right)\right)\right)$, the port is less profitable than before the upgrade. If the profits of port after implementation of renewal are lower than those of the previous one, the motivation for implementing the policy will be greatly reduced. Proposition 3 illustrates the comparison of the profits of port before and after the implementation of the policy under government subsidies. It is important for the government to control the profit of the port in a reasonable range by adjusting the size of $t$.

Proposition 4. When $t \in R^{+} \cap C_{U} B$, the port obtains benefits, where $B \in\left(\left(\left(\left(w-c_{p}\right) \mu-\sqrt{\mu^{2}\left(c_{p}-w\right)^{2}+2 k_{p}^{2}\left(c_{p}-w\right)}\right) /\right.\right.$ $\left.\left.k_{p}\right),\left(\left(\left(w-c_{p}\right) \mu+\sqrt{\mu^{2}\left(c_{p}-w\right)^{2}+2 k_{p}^{2}\left(c_{p}-w\right)}\right) / k_{p}\right)\right)$. The government can provide targeted subsidies to enterprises and avoid the negative situation of port income because of low subsidies through the scope of port subsidy coefficient. At the same time, the government can save money and avoid excessive subsidies. If the port is in a loss state after renewal, the implementation of the new policy may be difficult to carry out. Proposition 4 shows that ift is determined whether the shipping enterprises under the government subsidies are profitable after the implementation of the new policy.

\section{Revenue Sharing Contract}

4.1. Revenue Sharing Contract Model. Shipping enterprises bear the important responsibility of environmental cleaning in emission control areas. When the ratio of their income to cost is far less than that of ports, unfairness produce will occur, and the willingness of shipping enterprises to improve equipment will be largely reduced. Therefore, ports should share $\varphi$ proportion of income to shipping enterprises, and $1-\varphi$ part of the revenue left to themselves to promote the technical update of shipping enterprises and actively cooperate with green shipping. $\varphi$ is the profit sharing coefficient.

Profit function of the ports:

$$
\pi_{p}\left(q^{*}, e^{*}, \varphi\right)=(1-\varphi) w q^{*}-c_{p} q^{*}-\frac{1}{2} k_{p} e^{*^{2}}+t q^{*} e^{*}
$$

Profit function of shipping enterprises:

$$
\pi_{c}\left(q^{*}, e^{*}, \varphi\right)=\varphi w q^{*}+p(x \wedge q)-w q^{*}-c_{c} q^{*}-\frac{1}{2} k_{c} e^{*^{2}}+\lambda e^{*} .
$$

When the government subsidy is known, that is, when $\lambda$ and $t$ are determined, the interests of the port and shipping companies before the transformation are not less than the benefits after the transformation; then, $\varphi$ should meet the following inequalities:

$$
\begin{aligned}
& \pi_{c}\left(q^{*}, e^{*}, \varphi\right) \geq \pi_{c}\left(q^{o}\right), \\
& \pi_{p}\left(q^{*}, e^{*}, \varphi\right) \geq \pi_{p}\left(q^{o}\right) .
\end{aligned}
$$

The following can be obtained by solving equations (15) and (16):

$$
\begin{aligned}
& \underline{\varphi}=\frac{(1 / 2) k_{c} e^{2}+\left(w \mu+c_{c} \mu-p \mu-\lambda\right) e}{w\left(q^{o}+u e\right)} \\
& \bar{\varphi}=\frac{e\left(w \mu-c_{p} \mu+t q^{o}\right)+e^{2}\left(t \mu-(1 / 2) k_{p}\right)}{w\left(q^{o}+u e\right)} .
\end{aligned}
$$

The two previous equations show that when $\varphi$ belongs to $(\varphi, \bar{\varphi})$, ports and shipping enterprises make more profits than before they invest in updating equipment. Thus, ports and shipping enterprises will be enticed to upgrade equipment. 
4.2. Bargaining Model of Revenue Sharing. The bargaining model is used to determine the optimal value of $\varphi$ to determine the optimal proportion of allocation.

The port and shipping enterprise are the two parties to the bargaining model. One makes a bid first, while the other chooses to accept or reject. The port-oriented port-navigation service supply chain has a game behavior, wherein the port as a first-bid party has a first-mover advantage. Suppose the discount factors of ports and shipping enterprises are $\delta_{1}$ and $\delta_{2}$, respectively. The discount factor indicates the patience of both parties. A small discount factor indicates the degree of patience of the participants, which leads to the active termination of the game process as far as possible and acceptance of the other party's bid. A large discount factor means extra patience in the participant and increased likelihood that he will persist in the game and gain profits.

Suppose $X_{1}$ represents the port's share in the first stage of the game; then, $1-X_{1}$ is the shipping enterprise's share in the first stage. $X_{i}$ and $1-X_{i}$ represent the share allocated by the port and shipping enterprises in phase $i$, respectively. Considering the patience of the actual participants, the game will end in $t$ period, and the discount values of both sides are $\delta_{1}^{t-1} X_{t}$ and $\delta_{2}^{t-1}\left(1-X_{t}\right)$, respectively. The equilibrium solution of Rubinstein bargaining model is $X=\left(\left(1-\delta_{2}\right) /\right.$ $\left.\left(1-\delta_{1} \delta_{2}\right)\right)$.

The new equilibrium solution can be obtained as follows because of the constraint condition $\varphi \in(\varphi, \bar{\varphi})$ :

$$
X=\frac{\left(1-\delta_{2}\right)(\underline{\varphi}, \bar{\varphi})}{1-\delta_{1} \delta_{2}}+\underline{\varphi} .
$$

Proposition 5. When the revenue sharing rate $\varphi$ takes the following value,

$$
\varphi=\frac{\left(1-\delta_{2}\right)(\bar{\varphi}-\underline{\varphi})}{1-\delta_{1} \delta_{2}}+\underline{\varphi},
$$

the supply chain can be coordinated. Port and shipping companies can obtain their own ideal share of income with the different degrees of patience of the two enterprises in the negotiation process. Formula (20) shows that if the port has more patience, more profits can be derived. Actually, the port always has additional patience and owns advantages in competition.

The profit ratio of shipping enterprises is

$$
1-\varphi=1-\left(\frac{\left(1-\delta_{2}\right)(\bar{\varphi}-\underline{\varphi})}{1-\delta_{1} \delta_{2}}+\underline{\varphi}\right) .
$$

\section{Numerical Analysis}

In this section, we employ numerical examples to explore more insight of equilibriums instead. To be consistent with the previous studies, the specific values of the parameters in our numerical analysis can be set as follows:

Assuming that shipping market demand is subject to the uniform distribution of $[20,40]$. Table 1 shows the values of other parameters.
TABLE 1: Basic parameters.

\begin{tabular}{lcccccccc}
\hline Parameters & $c_{p}$ & $c_{c}$ & $w$ & $p$ & $k_{p}$ & $k_{c}$ & $t$ & $\lambda$ \\
\hline Value & 8 & 10 & 15 & 30 & 2500 & 1000 & 30 & 70 \\
\hline
\end{tabular}

5.1. Profit Analysis of Port and Shipping Enterprises. Equation (5) can be calculated by substituting the data in Table 1. The optimal order service volume of shipping enterprises before equipment upgrading is 23.3. After the improvement and upgrading of equipment, the optimal order quantity obtained from formula (11) is 36.4 as shown in Table 2, wherein the green index of emission control area is 0.437 .

In Table 2, the total profit of shipping enterprises before upgraded equipment is 108.2, and the total profit of port is 163.3. According to formula (13), when the subsidy coefficient of the government to the shipping enterprise is 68.5, the profit of the shipping enterprise is 108.2 unchanged, and when the one-time subsidy coefficient is 70 , the profit of the shipping enterprise is 109.1 .

Figure 2 illustrates the change in shipping enterprises with the green index under different government subsidies. When $t=30$, Figure 2 describes the income of shipping enterprises under different green indexes and provides the income of shipping enterprises under five different subsidies from the government. According to Figure 2, no matter what kind of subsidy, when the green index of emission control area is approximately 0.4 , the profit of shipping enterprises is the largest. On this basis, with the gradual increase and decrease in the green index, the profit of shipping enterprises will decrease. Meanwhile, as the government's subsidy to shipping enterprises slowly increases, the profits of shipping enterprises increase with a certain green index.

For shipping enterprises, when $t$ takes different values, the different optimal order quantities in Table 3 can be derived. When $t$ is 0 , the optimal green index is 0 ; that is, the shipping enterprises do not update equipment. With the increase in $t$, the optimal order quantity is also increasing. When the green index is definite, the port revenue increases with the increase in $t$.

Figure 3 depicts the change in port profits with the green index. The figure shows that when $t$ is certain, the port profits first increase and then decrease within a certain range of the green index in the emission control area. With the increase in the green index, when $t$ is small, the port profits will be negative. When the government subsidy coefficient and the green index of the emission control zone are small, the port can obtain benefits, and the benefits are higher than those of the port without a green renewal plan. When the government subsidy coefficient is large, the emission control area can still gain benefits even if it is in the case of a high green index. A high government subsidy coefficient will also place the maximum profit of the port at the highest. However, with the continuous increase in the green index, the port profit will somewhat decrease. When the subsidy coefficient is low and the green index is high, the port income will be lower than before the green equipment is updated, which is likely to cause negative income. 
TABle 2: Profit before and after investment.

\begin{tabular}{lccc}
\hline & Shipping company & Port & Optimal order quantity \\
\hline Before investment & 108.2 & 163.3 & 23.3 \\
After investment & 109.1 & 494.1 & 36.4 \\
\hline
\end{tabular}

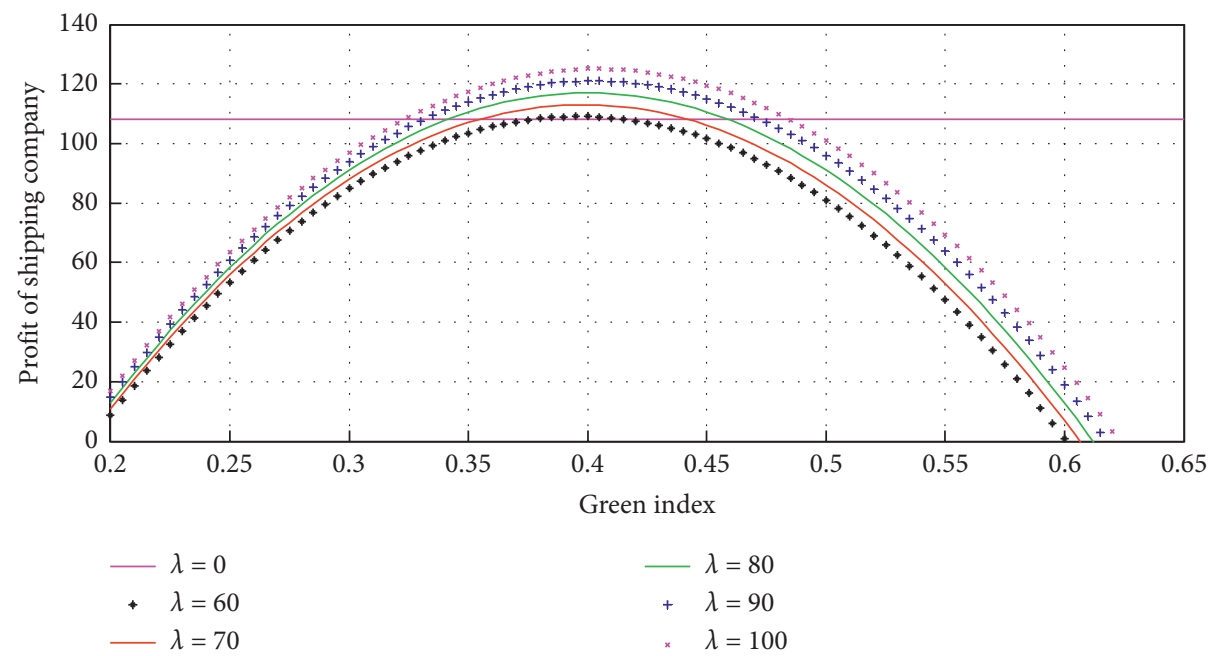

Figure 2: Profit of shipping company under different levels of the green index.

TABLE 3: Optimal order quantity under different subsidy coefficients of the government.

\begin{tabular}{cccccc}
\hline$t$ & 0 & 10 & 20 & 30 & 40 \\
\hline$q$ & 23.3 & 26.51 & 30.7 & 36.4 & 44.9 \\
\hline
\end{tabular}

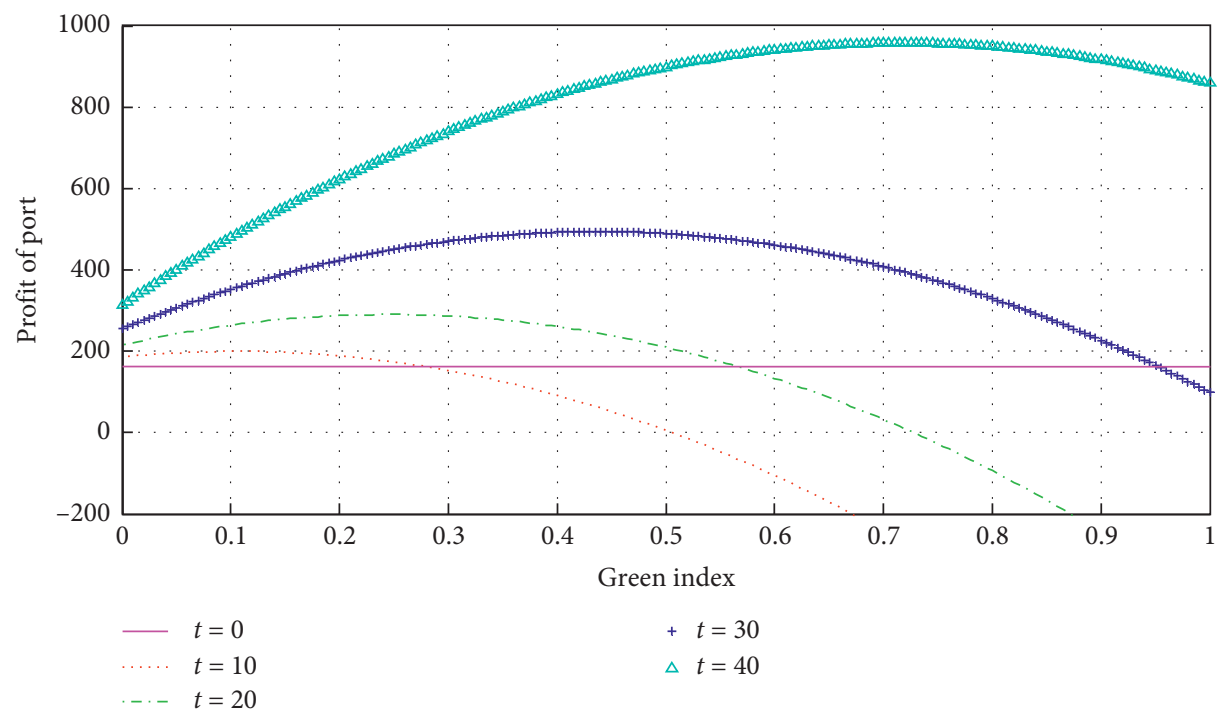

Figure 3: Port profits under different levels of the green index.

5.2. Numerical Simulation of Revenue Sharing. Under the condition that other parameters mentioned above remain unchanged, the subsidy coefficient of the government to the port's unit service volume is 30 , and the subsidy coefficient of the government to the shipping enterprise is 68.5. Joint equations (15) and (16) obtain $0 \leq \varphi \leq 0.605$. On this basis, Figure 4 shows the profit of port and shipping enterprises.

With the increase in port sharing coefficient $\varphi$, the profit of shipping enterprises also increases, whereas the profit of the port itself decreases. When $\varphi$ is 0 , that is, the port does 


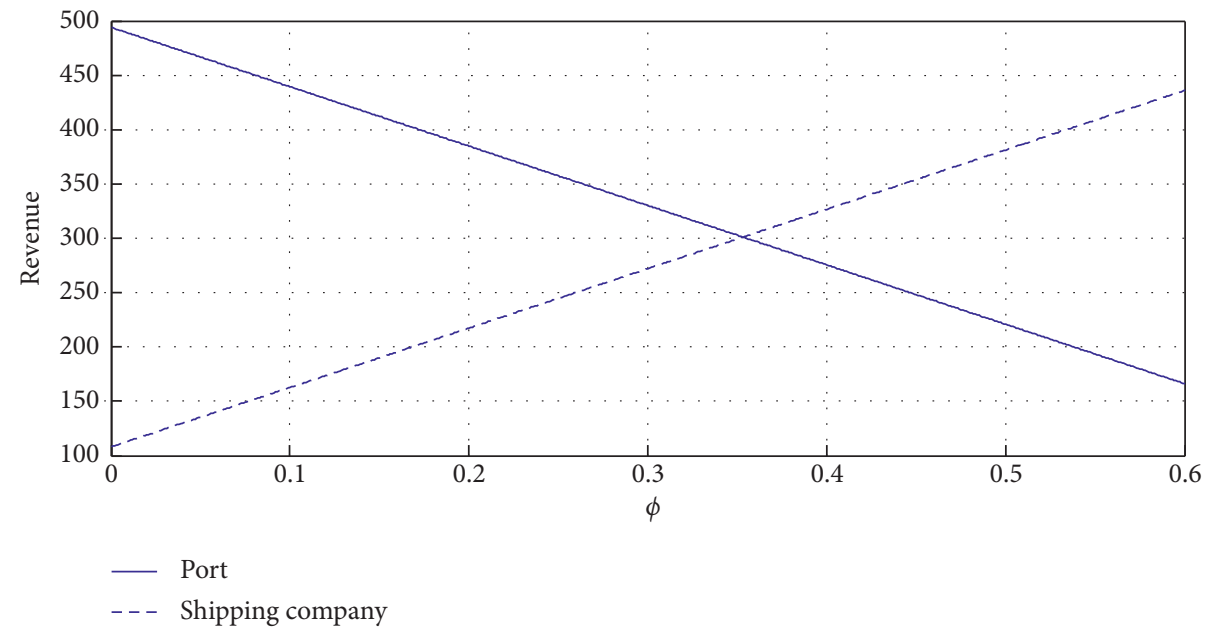

FIgURE 4: Profit and profit sharing coefficient of port and shipping enterprises.

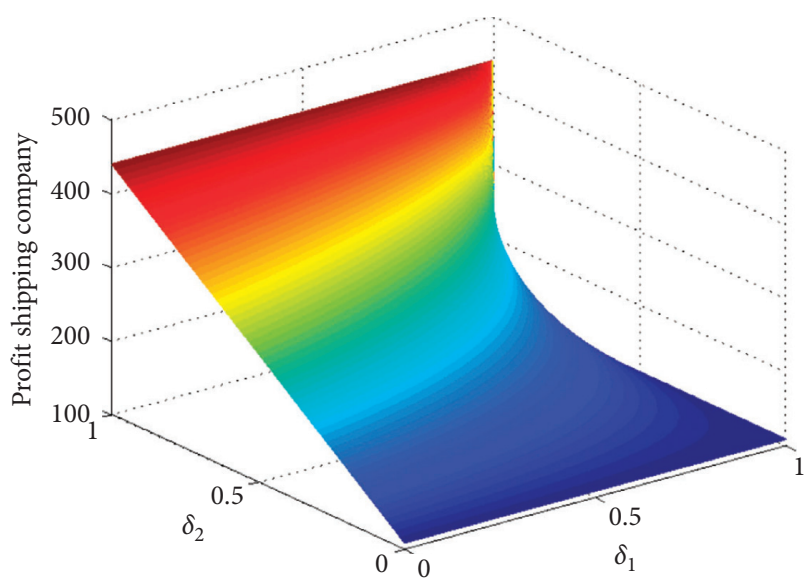

FIGURE 5: Revenue in the bargaining of shipping enterprises.

not carry out revenue sharing, the profit of the shipping enterprise is 108.2. When the port sharing coefficient $\varphi$ is 0.605 , the port profit is 163.3 before the investment update.

Assuming that the discount factors of ports and shipping enterprises are 0.9 and 0.8 , respectively, where other conditions remain unchanged, $\varphi$ can be obtained according to formula (20) to 0.173 . The port will be 0.173 part of revenue through the revenue sharing to the shipping enterprises. The remaining 0.827 part is reserved for its own income to realize revenue sharing. At this point, the profit of the shipping enterprise is 202.7, and the port profit is 399.5. Figures 2 and 5 show that the change in the discount coefficient of ports and shipping enterprises has a greater impact on the change in profits than government subsidies alone. The profit changes in shipping enterprises after the port and shipping enterprises carry out revenue sharing are larger than the profit changes only based on government subsidies to shipping enterprises. This finding indicates that revenue sharing can better regulate the revenue of shipping enterprises and increase the enthusiasm of shipping enterprises for green shipping.

An interesting finding is as follows: if the shipping company remains patient and negotiates with the port, it will be able to make extra profits. However, shipping companies commonly have a limited chance to bargain with port due to their disadvantages.

\section{Conclusions}

This paper studied how to keep the balance between the cost increase and the benefit caused by the ports and shipping enterprises' upgrading of equipment, which were driven by the policy of emission control zone and considering government subsidies and revenue sharing. On the basis of the idea of service supply chain, this study constructed a twostage service supply chain model of port and shipping enterprises. According to the ship environmental index, the concept of green index of emission control area was proposed. The study also discussed the profit changes in shipping enterprises and ports before and after the upgrading of emission reduction equipment under the government subsidy mechanism as well as the profit sharing coefficient and optimal sharing decision of ports and shipping enterprises in the supply chain.

This study provides a new perspective and solution for the innovation of green emission reduction theory of the navigation system. It also offers direction for the government, port, and shipping enterprises to make practical emission reduction strategies. In the course of the study, the following conclusions are obtained:

(1) In the process of implementing the ECA policy, the government subsidy mechanism directly affects the decision of port and navigation enterprises on the emission reduction equipment upgrade and the profit distribution of the port and shipping service supply chain, which is the key factor in the final implementation of the emission restraint policy.

(2) The government subsidy coefficient and the green index and the relationship between the two are the key factors that balance government subsidies, corporate earnings, and emission reduction targets. When the ECA green index is certain, a high 
government subsidy coefficient means high profits of ports and shipping enterprises. When the government subsidy coefficient is certain, the profits of ports and shipping enterprises increase within a certain green index range. Thus, the government can set the ECA green index to set the port subsidy coefficient in the emission control areas.

(3) By comparison, after the reduction and upgrading of the emission reduction, the profit of the port under the same conditions is much greater than the profit of the shipping enterprises. Thus, establishing a reasonable revenue sharing mechanism in the supply chain and realizing the mutual profit through bargaining optimization are necessary. The collaborative emission reduction led by the port enterprises can better promote the balance between the overall revenue improvement of the navigation system and the emission reduction through the example analysis.

In addition, this study does not just consider the emission reduction of ECAs as a separate individual but takes two companies into consideration. It considers the balance of costs and benefits based on the overall benefits of the supply chain. In this paper, an index that can measure the environmental improvement of the emission control area, namely, the ECAs' Green Index, provides a reference direction for the government to formulate the corresponding subsidy policy and achieve the aim of monitoring the effect of the ECAs' policy implementation.

This research may face some limitations in model hypothesis and parameter setting because it is based on the analysis and discussion of the secondary supply chain composed of "port-to-shipping" enterprises. Further research must examine the expansion of the multilevel port service supply chain. In addition, the ECA Green Index based on the Ship Environment Index provides a benchmark for assessing emission reduction effectiveness. However, the actual environmental improvement in the emission control area is not fully reflected. Future research must seek a diversified assessment indicator to measure the effects of green emission reduction effectively following a scientific approach.

\section{Data Availability}

The data used to support the findings of this study are available from the corresponding author upon request.

\section{Conflicts of Interest}

The authors declare that they have no conflicts of interest.

\section{Acknowledgments}

This research was supported by the National Key Research and Development Project (Grant no. 2019YFB1600401), Youth Program of National Natural Science Foundation of China (Grant no. 71503029), the State Key Program of National Natural Science of China (Grant no. 71831002), and Program for Innovative Research Team in University of Ministry of Education of China (IRT_17R13, 3132020501).

\section{References}

[1] M. Svindland, "The environmental effects of emission control area regulations on short sea shipping in Northern Europe: the case of container feeder vessels," Transportation Research Part D: Transport and Environment, vol. 61, no. B, pp. 423430, 2018.

[2] H. Lindstad, B. E. Asbjørnslett, and A. H. Strømman, "Reductions in greenhouse gas emissions and cost by shipping at lower speeds," Energy Policy, vol. 39, no. 6, pp. 3456-3464, 2011.

[3] H. Lindstad, B. E. Asbjørnslett, and A. H. Strømman, "The importance of economies of scale for reductions in greenhouse gas emissions from shipping," Energy Policy, vol. 46, pp. 386-398, 2012.

[4] Y.-T. Chang, H. Park, S. Lee et al., "Have emission control areas (ECAs) harmed port efficiency in Europe?" Transportation Research Part D: Transport and Environment, vol. 58, no. SI, pp. 39-53, 2018.

[5] T. Lee and H. Nam, "A study on green shipping in major countries: in the view of shipyards, shipping companies, ports, and policies," The Asian Journal of Shipping and Logistics, vol. 33, no. 4, pp. 253-262, 2017.

[6] R. Aronietis, C. Sys, E. V. Hassel et al., "Forecasting port-level demand for LNG as a ship fuel: the case of the port of Antwerp," Journal of Shipping \& Trade, vol. 1, no. 1, p. 2, 2016.

[7] K. Fagerholt, N. T. Gausel, J. G. Rakke et al., "Maritime routing and speed optimization with emission control areas," Transportation Research Part C: Emerging Technologies, vol. 52, pp. 57-73, 2015.

[8] L. Chen, T. L. Yip, and J. Mou, "Provision of emission control area and the impact on shipping route choice and ship emissions," Transportation Research Part D: Transport and Environment, vol. 58, no. SI, pp. 280-291, 2018.

[9] A. Linder, "Explaining shipping company participation in voluntary vessel emission reduction programs," Transportation Research Part D: Transport and Environment, vol. 61, no. B, pp. 234-245, 2018.

[10] K. Fagerholt and H. N. Psaraftis, "On two speed optimization problems for ships that sail in and out of emission control areas," Transportation Research Part D: Transport and Environment, vol. 39, pp. 56-64, 2015.

[11] M. E. Radwan, J. Chen, Z. Wan, T. Zheng, C. Hua, and $\mathrm{X}$. Huang, "Critical barriers to the introduction of shore power supply for green port development: case of Djibouti container terminals," Clean Technologies and Environmental Policy, vol. 21, no. 6, pp. 1293-1306, 2019.

[12] O. Schinas and D. Metzger, "A pay-as-you-save model for the promotion of greening technologies in shipping," Transportation Research Part D: Transport and Environment, vol. 69, pp. 184-195, 2019.

[13] H. Cui and T. Notteboom, "Modelling emission control taxes in port areas and port privatization levels in port competition and co-operation sub-games," Transportation Research Part D: Transport and Environment, vol. 56, pp. 110-128, 2017.

[14] K. F. Yuen, V. V. Thai, and Y. D. Wong, "The effect of continuous improvement capacity on the relationship between of corporate social performance and business performance in maritime transport in Singapore," Transportation Research Part E: Logistics and Transportation Review, vol. 95, pp. 62-75, 2016. 
[15] K. F. Yuen, X. Wang, Y. D. Wong et al., "Antecedents and outcomes of sustainable shipping practices: the integration of stakeholder and behavioural theories," Transportation Research Part E: Logistics and Transportation Review, vol. 108, pp. 18-35, 2017.

[16] J. S. L. Lam and K.-h. Lai, "Developing environmental sustainability by ANP-QFD approach: the case of shipping operations," Journal of Cleaner Production, vol. 105, pp. 275-284, 2015.

[17] A. Mjelde, Ø. Endresen, E. Bjørshol et al., "Differentiating on port fees to accelerate the green maritime transition," Marine Pollution Bulletin, vol. 149, p. 110561, 2019.

[18] L. M. Abadie and N. Goicoechea, "Powering newly constructed vessels to comply with ECA regulations under fuel market prices uncertainty: diesel or dual fuel engine?" Transportation Research Part D: Transport and Environment, vol. 67, pp. 433-448, 2019.

[19] L. M. Abadie, N. Goicoechea, and I. Galarraga, "Adapting the shipping sector to stricter emissions regulations: fuel switching or installing a scrubber?" Transportation Research Part D: Transport and Environment, vol. 57, pp. 237-250, 2017.

[20] H. Geerlings and R. Duin, "A new method for assessing $\mathrm{CO}_{2^{-}}$ emissions from container terminals: a promising approach applied in Rotterdam," Journal of Cleaner Production, vol. 19, no. 6-7, pp. 657-666, 2011.

[21] J. Krozer, K. Mass, and B. Kothuis, "Demonstration of environmentally sound and cost-effective shipping," Journal of Cleaner Production, vol. 11, no. 7, pp. 767-777, 2003.

[22] J.-K. Woo and D. S.-H. Moon, "The effects of slow steaming on the environmental performance in liner shipping," Maritime Policy \& Management, vol. 41, no. 2, pp. 176-191, 2014.

[23] L. Zhen, M. Li, Z. Hu, W. Lv, and X. Zhao, "The effects of emission control area regulations on cruise shipping," Transportation Research Part D: Transport and Environment, vol. 62, pp. 47-63, 2018.

[24] D. Sheng, Q. Meng, and Z.-C. Li, "Optimal vessel speed and fleet size for industrial shipping services under the emission control area regulation," Transportation Research Part C: Emerging Technologies, vol. 105, pp. 37-53, 2019.

[25] J. J. Corbett, H. Wang, and J. J. Winebrake, "The effectiveness and costs of speed reductions on emissions from international shipping," Transportation Research Part D: Transport and Environment, vol. 14, no. 8, pp. 593-598, 2009.

[26] W. Shi, Y. Xiao, Z. Chen, H. McLaughlin, and K. X. Li, "Evolution of green shipping research: themes and methods," Maritime Policy \& Management, vol. 45, no. 7, pp. 863-876, 2018.

[27] M. Acciaro, T. Vanelslander, C. Sys et al., "Environmental sustainability in seaports: a framework for successful innovation," Maritime Policy \& Management, vol. 41, no. 5, pp. 480-500, 2014.

[28] T. Longva, M. S. Eide, and R. Skjong, "Determining a required energy efficiency design index level for new ships based on a cost-effectiveness criterion," Maritime Policy \& Management, vol. 37, no. 2, pp. 129-143, 2010.

[29] X. Qiu, E. Y. C. Wong, and J. S. L. Lam, "Evaluating economic and environmental value of liner vessel sharing along the maritime silk road," Maritime Policy \& Management, vol. 45, no. 3, pp. 336-350, 2018.

[30] N. M. Modak and P. Kelle, "Using social work donation as a tool of corporate social responsibility in a closed-loop supply chain considering carbon emissions tax and demand uncertainty," Journal of the Operational Research Society, pp. 1-17, 2019.
[31] N. M. Modak and P. Kelle, "Managing a dual-channel supply chain under price and delivery-time dependent stochastic demand," European Journal of Operational Research, vol. 272, no. 1, pp. 147-161, 2018.

[32] S. Panda, N. M. Modak, and L. E. Cárdenas-Barrón, "Coordinating a socially responsible closed-loop supply chain with product recycling," International Journal of Production Economics, vol. 188, pp. 11-21, 2017.

[33] N. M. Modak, D. K. Ghosh, S. Panda, and S. S. Sana, "Managing green house gas emission cost and pricing policies in a two-echelon supply chain," CIRP Journal of Manufacturing Science and Technology, vol. 20, pp. 1-11, 2018.

[34] C. F. Hsueh, "Improving corporate social responsibility in a supply chain through a new revenue sharing contract," International Journal of Production Economics, vol. 151, pp. 214-222, 2013.

[35] N. M. Modak, "Exploring omni-channel supply chain under price and delivery time sensitive stochastic demand," Supply Chain Forum: An International Journal, vol. 18, no. 4, pp. 218-230, 2017.

[36] Q.-p. Wang and D.-z. Zhao, "Revenue-sharing contract of supply chain based on consumer's preference for low carbon products," Chinese Journal of Management Science, vol. 22, no. 9, pp. 106-113, 2014.

[37] Y. Gu and S. W. Wallace, "Scrubber: a potentially overestimated compliance method for the Emission Control Areas," Transportation Research Part D: Transport and Environment, vol. 55, pp. 51-66, 2017.

[38] K. Cullinane and R. Bergqvist, "Emission control areas and their impact on maritime transport," Transportation Research Part D: Transport and Environment, vol. 28, pp. 1-5, 2014.

[39] O.-P. Hilmola, "Shipping sulphur regulation, freight transportation prices and diesel markets in the Baltic Sea region," International Journal of Energy Sector Management, vol. 9, no. 1, pp. 120-132, 2015. 